\title{
6. SITE 452: MESOZOIC PACIFIC OCEAN BASIN ${ }^{1}$
}

\author{
Shipboard Scientific Party²
}

\section{HOLE 452}

Date occupied: 23 March 1978

Date departed: 24 March 1978

Time on hole: 29.3 hours

Position (latitude; longitude): $17^{\circ} 40.19^{\prime} \mathrm{N} ; 148^{\circ} 37.73^{\prime} \mathrm{E}$

Water depth (sea level; corrected $\mathrm{m}$, echo-sounding): 5858

Water depth (rig floor; corrected $\mathrm{m}$, echo-sounding): 5868

Bottom felt (m, drill pipe): 5838

Penetration (m): 28.0

Number of holes: 1

Number of cores: 3

Total length of cored section $(\mathrm{m}): \mathbf{2 8 . 0}$

Total core recovered $(\mathrm{m}): 27.35$

Core recovery $(\%): 97.7$

Oldest sediment cored:

Depth sub-bottom $(\mathrm{m}) ; 9.0-18.5$

Nature: pelagic clay

Age: Pleistocene

Measured velocity $(\mathrm{km} / \mathrm{s}): 1.518$

Principal results: See Principal results for Hole 452A.

\section{HOLE 452A}

Date occupied: 24 March 1978

Date departed: 27 March 1978

Time on hole: 57 hours

Position: $17^{\circ} 40.17^{\prime} \mathrm{N} ; 148^{\circ} 37.75^{\prime} \mathrm{E}$

Water depth (sea level; corrected m, echo-sounding): 5860

Water depth (rig floor; corrected $\mathrm{m}$, echo-sounding): 5870

Bottom felt (m, drill pipe): 5872.5

Penetration (m): 46.5

Number of holes: 1

Number of cores: 5

Total length of cored section $(\mathrm{m}): 46.5$

\footnotetext{
1 Initial Reports of the Deep Sea Drilling Project, Volume 60.

2 Donald M. Hussong (Co-Chief Scientist), Hawaii Institute of Geophysics, Honolulu, Hawaii; Seiya Uyeda (Co-Chief Scientist), Earthquake Research Institute, University of Tokyo, Tokyo, Japan; René Blanchet, Université de Bretagne Occidentale, Brest, France; Ulrich Bleil, Institut für Geophysik, Ruhr Universität, Bochum, Federal Republic of Ger many; C. Howard Ellis, Marathon Oil Company, Denver Research Center, Littleton, Colorado; Timothy J. G. Francis, Institute of Oceanographic Sciences, Surrey, United Kingdom; Patricia Fryer, Hawaii Institute of Geophysics, Honolulu, Hawaii; Ki-lti Horai, LamontDoherty Geological Observatory, Palisades, New York; Stanley Kling, Marine Life Research View Lane, Leucadia, California); Arend Meijer, Department of Geosciences, University of Arizona, Tucson, Arizona: Kazuaki Nakamura, Earthquake Research Institute, University of Tokyo, Tokyo, Japan; James H. Natland, Deep Sea Drilling Project, Scripps Institution of Oceanography, La Jolla, California; Gordon H. Packham, Department of Geology and Geophysies, University of Sydney, Sydney, N.S.W. Australia; and Anatoly Sharaskin, Vernadsky Institute of Geochemistry, U.S.S.R. Academy of Sciences, Moscow, U.S.S.R.
}

Total core recovered $(\mathrm{m}): 21.72$

Core recovery $(\%): 46.7$

Oldest sediment cored:

Depth sub-bottom (m): 37

Nature: radiolarian mudstone and chert

Age: Campanian

Measured velocity $(\mathrm{km} / \mathrm{s}): 2.99$

Principal results: We were not able to penetrate the shallow siliceous mudstone and chert encountered at this site. A surprisingly thin layer of Neogene-Quaternary clay overlies the Cretaceous porcellanite and chert. The lack of a substantial Neogene sedimentary section in this relatively undisturbed ocean basin apparently reflects a very low sediment accumulation rate over much of the western Pacific. This is a consequence of low productivity, depth of the sea floor below the calcite compensation depth, and no major terrigenous or volcanogenic sediment sources.

\section{BACKGROUND AND OBJECTIVES}

Site 452, the easternmost target of the South Philippine Sea transect, is located in the northern Mariana Basin on deep old Pacific plate crust. The site was chosen to serve as the oceanic plate reference section for comparison with holes drilled on the inner trench wall, on the Mariana Arc, and in the Mariana Trough active back-arc basin. Thus, determination of the complete sediment sequence as well as the age and nature of the basement was the drilling objective. The site was to be representative of a typical regional upper crustal section. To meet these criteria, the site was chosen to be close to the trench, but at a water depth of less than 6000 meters (Fig. 1), which is approximately the depth at which the upper plate begins to be broken by normal faulting as the lithosphere bends prior to subduction. The site is also on the trench side of the outer gravity high (Hussong and Fryer, this volume).

Although the northern portion of the Mariana Basin contains the Magellan Seamounts, Site 452 was located more than 35 kilometers from the nearest seamount.

During the H.I.G. site surveys, magnetic anomaly lineations-suggestive of sea-floor-spreading anomalies-were located in the northern Mariana Basin. Hussong and Fryer (this volume) have tentatively identified these anomalies and suggests that Site $\mathbf{4 5 2}$ is located on crust formed at the time of Anomaly M-23, some 151 m.y. ago. We hoped that a hole to basement would check this age determination.

The site survey data and reflection profiles (Figs. 2 and 3) collected by the Challenger as the site was approached suggest that some 40 meters of surface sediments overlies approximately 200 meters of slightly consolidated sediments with velocities estimated at less than $2 \mathrm{~km} / \mathrm{s}$. Beneath this zone, 400-600 meters of material with a velocity of $3-3.5 \mathrm{~km} / \mathrm{s}$ was thought to overlie the 


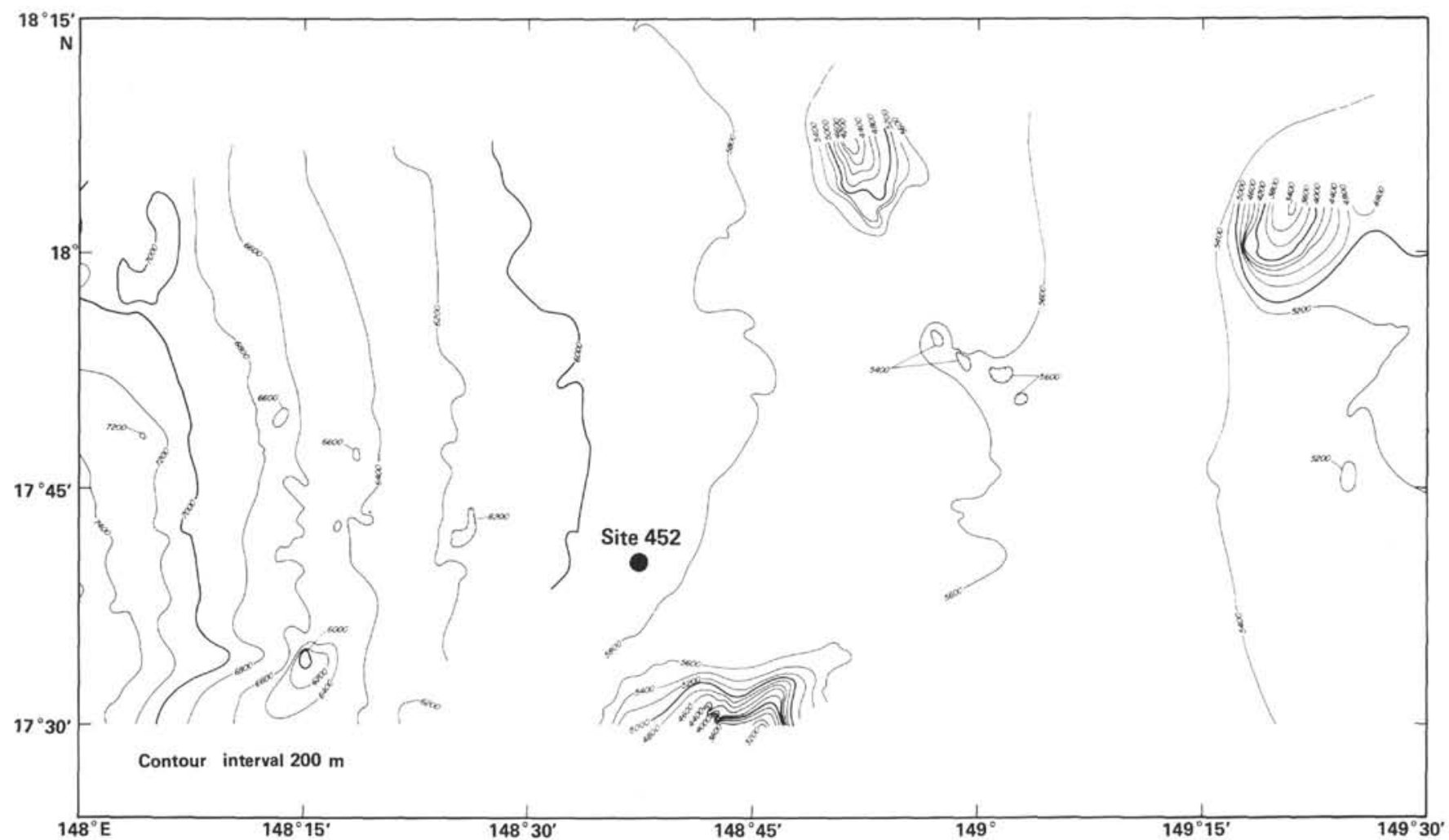

Figure 1. Bathymetry in the vicinity of Site 452 , from Hussong (this volume).

first rocks with velocities high enough ( $>4 \mathrm{~km} / \mathrm{s}$ ) to be unweathered igneous rocks (LaTraille and Hussong, 1980).

The site was to be continuously cored in order to obtain the complete biostratigraphic sequence, and we hoped to obtain a basement igneous rock sample to check the age of formation and to provide a paleomagnetic identification of the latitude of crustal formation.

\section{OPERATIONS}

At 1812 on 21 March 1978, the D/V Glomar Challenger departed Guam for survey area SP-1 in the north Mariana Basin. Underway geophysical profiles, including $3.5-\mathrm{kHz}$ and $12-\mathrm{kHz}$ bathymetry, air-gun source reflection seismic, and total intensity magnetics, commenced at 2052 when the ship was a few miles north of the Agana Commercial Port; they were run continuously to SP-1. The drilling target is the easternmost site of the Mariana Arc-South Philippine Sea transect, and before arrival its location was properly identified on the basis of site survey data. Although a sparsity of satellite passes during the approach degraded our navigational control, a $3.5-\mathrm{kHz}$ double-life beacon was dropped at 1358 on 23 March, during the ship's first crossing of the drill site region, when the sea-floor depth and character matched the site survey data. The bottom was flat, appeared undisturbed, and was at a depth of about 58505900 meters.

The Challenger made a second pass over the beacon using only a small air gun ( $20 \mathrm{cu}$. in.) and the recording gear set to a higher bandwidth in an attempt to improve resolution of the upper sediment column, then retrieved the streamed gear by 1450 . The beacon settled on a slight $(25 \mathrm{~m})$ bathymetric high, so we positioned the ship 1000 feet to the south where water depth matched the local average of 5858 meters.

A standard F94CK drill bit was selected and a normal 120 -meter bottom-hole assembly was rigged. Commencing at 1548, 22 March, the bottom-hole assembly and drill string was lowered. At 0815 on $24 \mathrm{March}$, the bit was judged to be some 30 meters off the sea floor, based on the estimated length of drill string deployed and the corrected PDR depth readings. At this time the Bowen rotation sub-assembly and pup joint were put in the drill string. Just prior to this an unexplained 40,000-lb. decrease in drill-string weight occurred.

At 0950 the bit was lowered from a drill-string depth of 5838 meters to 5847 meters to obtain a mudline core. Although the drill string should have entered the bottom during the lowering, no weight variation was noted by the driller. Subsequently, the first attempt to recover the mudline core failed because the inner coring barrel was apparently jammed in the bottom of the drill string, resulting in the shearing of the safety pin in the overshot (core retrieval tool). The overshot was rerigged, and on the second attempt the core was retrieved. The core was full of mud suggesting that the bottom had been penetrated at 5838 meters or shallower. A second core, from 9 to 18.5 meters below the apparent sea floor, also jammed in the bottom of the drill string, but was finally retrieved full of mud. The third core jammed completely, and when all attempts to retrieve the core failed 


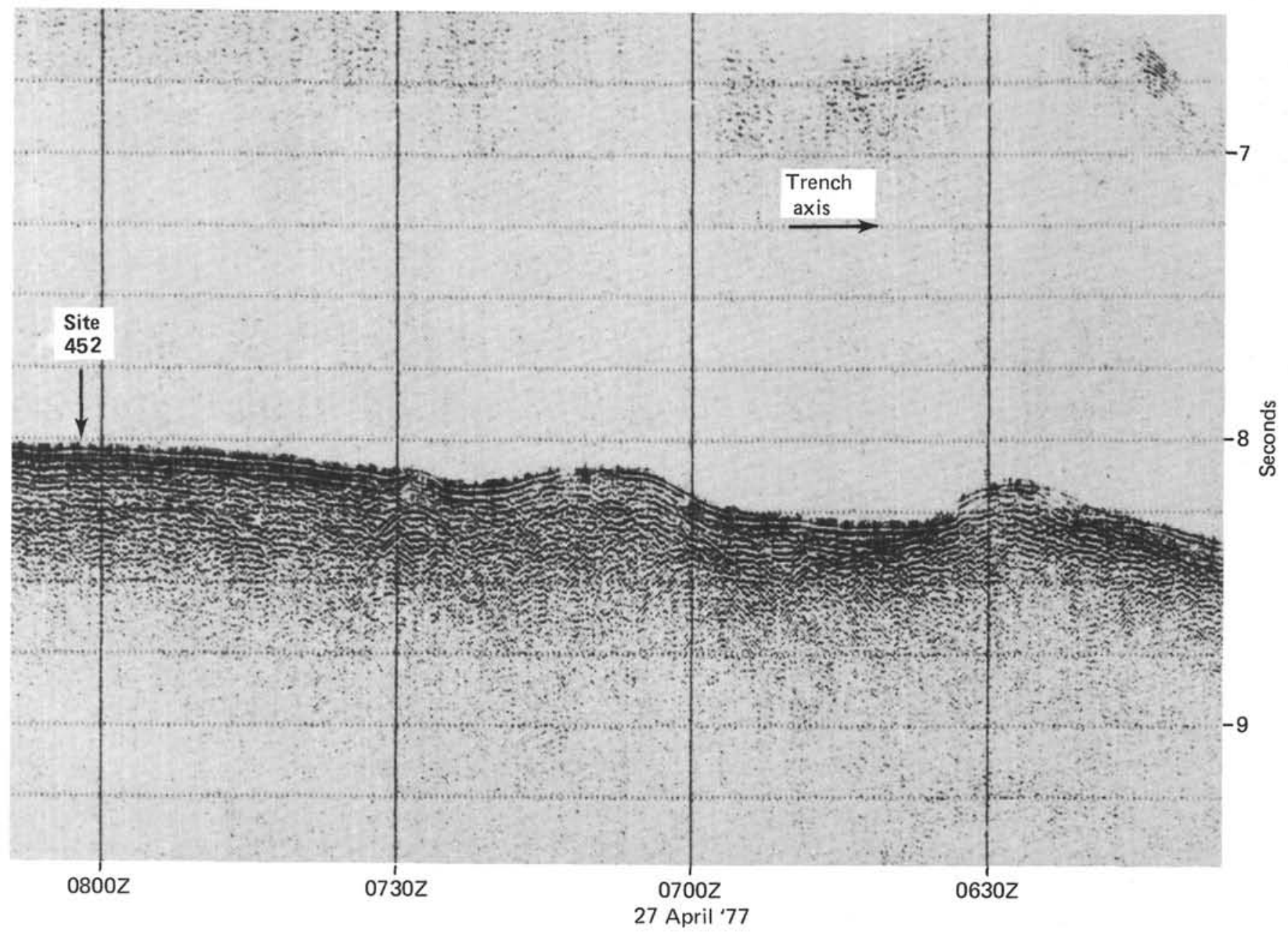

Figure 2. Single-channel, air-gun reflection record collected by the R/V Kana Keoki along a course intersecting Site 452 . This record segment represents approximately $33 \mathrm{~km}$ of track on a course of $039^{\circ} \mathrm{T}$. Note that Site 452 is on undeformed sea floor, but is less than $10 \mathrm{~km}$ northeast of the first tensional faulting that increases to the west as the Pacific plate is bent prior to subduction.

the decision was made to retrieve the entire drill string. On completion of retrieval, at 0700 on 25 March, we found that the bottom bumper sub was bent, and the lower two drill collars, bit release mechanism, and drill bit were gone. The coring inner barrel was jammed in the third-from-the-bottom drill collar, with the core catcher protruding about a meter beneath the bottom of the severed bottom-hole assembly.

Our best guess is that the drill string was at least 30 meters longer than thought during lowering, and that the lower portion of the bottom-hole assembly broke off during premature contact with the sea floor. All the cores were then taken with the inner core barrel protruding from the bottom end of the remaining drill collar. The three Holes 452 cores are therefore valid samples, although their exact depth beneath the sea floor (listed in Table 1) is not well established.

A new bottom-hole assembly was rigged, while the ship offset 200 feet further south $(1200 \mathrm{ft}$. from the beacon). At 1615 on 25 March, the drill string started down for Hole 452A. Water depth based on corrected PDR readings was 5860 meters. A first mudline core was obtained on $26 \mathrm{March}$, at 0725 , and indicated a water depth of 5862.5 meters.

The third core, from 18.0 to 27.5 meters sub-bottom, encountered resistance and required bit rotation to penetrate the last three meters (Fig. 4). Fragments of radiolarian mudstone were found in the catcher of this core. The fourth and fifth cores recovered only 0.90 and 0.84 meters of clay with fragments of radiolarian chert, respectively, and required slow drilling. Raising the bit during the fifth core met with resistance, suggesting that the hole was caving in. During the attempt to drill the sixth core, we encountered constant torquing up of the bit and apparent caving of fragments into the hole.

After 50 minutes of drilling for the sixth core, the bit had still not penetrated as deep as the bottom of the fifth core. At this point, we judged the hole too unstable to continue drilling. This decision was reached largely because of the risk of loss of the bottom-hole assembly, which was still only half-way spudded into the bottom and which contained the only remaining top connector for the bit release system on the ship (the bit release was required for downhole logging, a priority mission of 


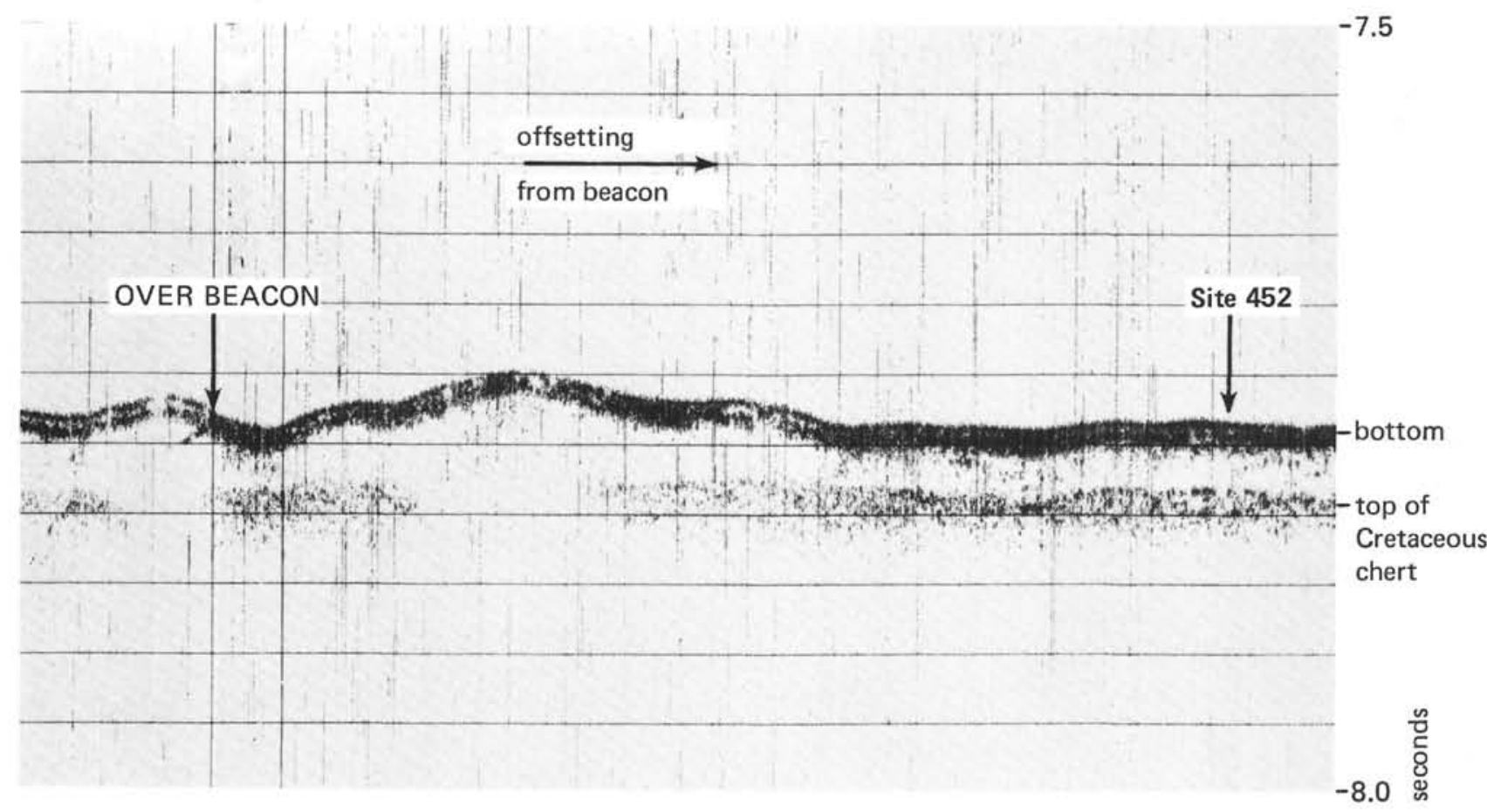

Figure 3. A portion of the Glomar Challenger 3.5-kHz record over Site 452, showing near-surface sub-bottom reflectors. The lower of these corresponds to a profound Cretaceous-Neogene disconformity.

Table 1. Coring summary, Site 452.

\begin{tabular}{|c|c|c|c|c|c|c|c|}
\hline Core & $\begin{array}{c}\text { Date } \\
\text { (March } \\
\text { 1978) }\end{array}$ & Time & $\begin{array}{l}\text { Depth from } \\
\text { Drill Floor } \\
\text { (m) }\end{array}$ & $\begin{array}{l}\text { Depth below } \\
\text { Sea Floor } \\
\text { (m) }\end{array}$ & $\begin{array}{c}\text { Length } \\
\text { Cored } \\
\text { (m) }\end{array}$ & $\begin{array}{l}\text { Length } \\
\text { Recovered } \\
\text { (m) }\end{array}$ & $\begin{array}{c}\text { Recovery } \\
\left(\%_{0}\right)\end{array}$ \\
\hline \multicolumn{8}{|l|}{ Hole 452} \\
\hline 1 & 24 & 1308 & $5838.0-5847.0$ & $0.0-9.0$ & 9.0 & 8.76 & 97.3 \\
\hline 2 & 24 & 1507 & $5847,0-5856.5$ & $9.0-18.5$ & 9.5 & 9.55 & 100 \\
\hline 3 & 25 & 1205 & $5856.5-5866.0$ & $18.5-28.0$ & 9.5 & 9.04 & 95 \\
\hline \multicolumn{8}{|c|}{ Hole 452A } \\
\hline 1 & 26 & 0840 & $5872.5-5881.0$ & $0.0-8.5$ & 8.5 & 8.14 & 95.8 \\
\hline 2 & 26 & 1015 & $5881.0-5890.5$ & $8.5-18.0$ & 9.5 & 3.95 & 41.6 \\
\hline 3 & 26 & 1158 & $5890.5-5900.0$ & $18.0-27.5$ & 9.5 & 7.89 & 83.0 \\
\hline 4 & 26 & 1353 & $5900.0-5909.5$ & $27.5-37.0$ & 9.5 & 0.9 & 0.01 \\
\hline 5 & 26 & 1608 & $5909.5-5919.0$ & $37.0-46.5$ & 9.5 & 0.84 & 0.01 \\
\hline Total & & & & & 24.5 & 49.07 & 65.86 \\
\hline
\end{tabular}
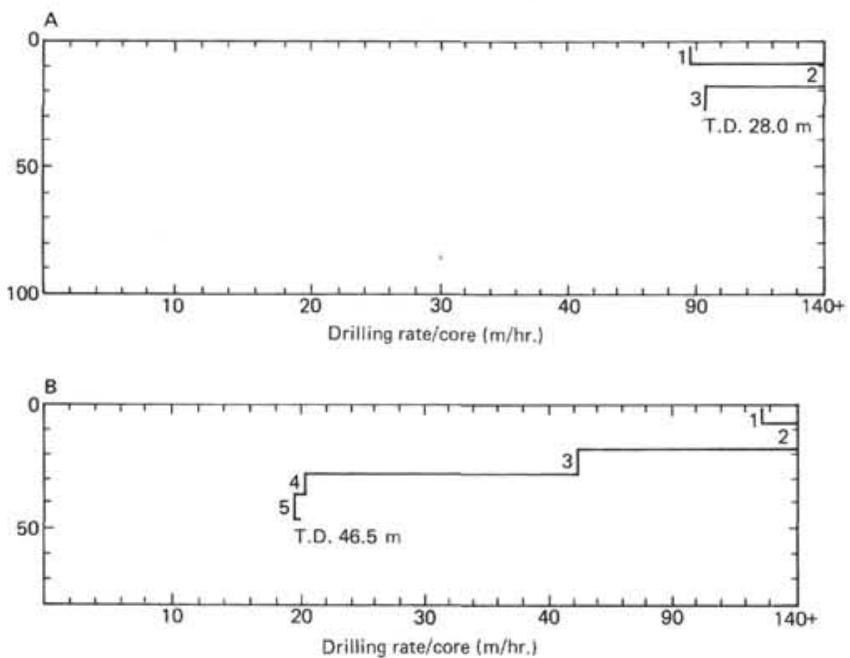

Figure 4 . Drilling rate per core $(\mathrm{m} / \mathrm{hr}$.). A. Hole 452 . B. Hole $452 \mathrm{~A}$. Core numbers are indicated on plots. T.D. $=$ total depth.
Leg 60). The hole was abandoned and the drill string was retrieved by 0415 on 27 March. When the drill string was aboard, the sixth core was removed; the liner contained above five meters of drilling breccia containing chert fragments.

\section{LITHOLOGY OF SEDIMENTS}

Three cores from Hole 452, five cores from Hole $452 \mathrm{~A}$, and Hawaii Institute of Geophysics site survey core SP-1A were studied. The latter is 11.65 meters long and was taken in 6012 meters of water at $17^{\circ} 46^{\prime} \mathrm{N}$ and $148^{\circ} 32^{\prime}$ E. Hole 452 and Core SP-1A intersected only pelagic clays, but Cretaceous radiolarian rocks were drilled and recovered in the last two cores of Hole 452A. The succession at the site has been accordingly divided into two units (Fig. 5).

Unit I- 0 to 25 meters sub-bottom; pelagic clay (Core SP-1A, Hole 452, Hole 452A)

Unit II-25 to 46.5 meters sub-bottom; radiolarian mudstone and chert (Hole 452A)

\section{Unit I-Pelagic Clay (0 to $25 \mathrm{~m}$ sub-bottom)}

The thickness of this unit was determined by consideration of the drilling rates in Hole 452A during the cutting of Core 3. Considerable torque on the drill string was experienced during the later stage of drilling; in spite of this, only pelagic clays were obtained in this core. Radiolarian rocks were not recovered until the core catcher of Core 4 . This means that the 27.35 meters of core recovered from the unit in Hole 452 is a little in excess of the thickness of the unit. Only about 21.5 meters of pelagic clay was recovered from Hole 452A after 46.5 meters of penetration. 


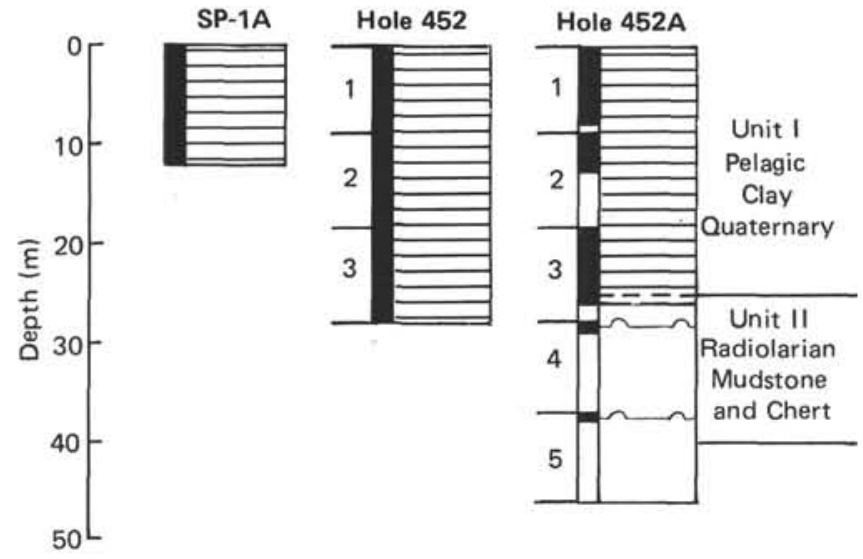

Figure 5. Summary lithologic columns for Holes 452 and 452A, and Core SP-1A.

The pelagic clay is moderate brown in the upper part and darker yellowish brown at deeper levels. The zeolite content is greater lower in the unit, while the upper part is richer in silt and micronodules. The principal component of the silt fraction is feldspar with much less abundant volcanic glass. In Sections 452-1-2 and 452A1-3, two coarse sand layers are present. The upper sand layer is 4 to $5 \mathrm{~cm}$ thick, and the lower one is $1 \mathrm{~cm}$ thick in Hole 452 and is represented by a row of grains in Hole 452A. These layers are well sorted and contain a great variety of rock fragments, including volcanic glass, chert, manganese nodules, quartz, feldspar, and zeolites.

The cores that are almost devoid of layering until Core 3, where in the upper part of Section 452-3-4, and the lower part of Section 452A-4-3, moderate yellowish brown bands appear. These bands are richer in zeolites and poorer in micronodules than the overlying clay. There is at least 3 or 4 meters of this banded sediment. Beneath these in both cores is drilling breccia containing both zeolite-rich and zeolite-poor lithologies.

The SP-1A core contains pale layers similar to those described above in its upper part only. This core shows mottling throughout, suggesting bioturbation. We assume that these structures were destroyed in the cores by the drilling process.

All three cores contain scattered manganese nodules several centimeters in diameter.

\section{Unit II-Radiolarian Mudstone and Chert (25 to $46.5 \mathrm{~m}$ sub-bottom)}

Only fragments of the rocks from this unit were recovered. Two lithologies only are known-radiolarian mudstone and chert. The mudstone is dark yellowish brown with a conchoidal fracture. The radiolarians are infilled with clear chalcedony.

The chert is banded and generally brown and grayish orange in color and was recovered only in Core 5. After pulling up the drill string to retrieve the core, it was not possible to drill down to the level at which Core 5 was taken. On recovery of the drill string, the core barrel contained about 3 meters of chert chips.

\section{BIOSTRATIGRAPHY}

\section{Summary}

Although the pelagic clay (Unit I) cannot be dated on the basis of sparse radiolarians and calcareous nannofossils, ichthyoliths indicate that it ranges from Miocene to Recent. The underlying chert (Unit II) contains Cretaceous radiolarians and there are individual radiolarians, apparently originating from the chert assemblage, reworked into the pelagic clay as high as the middle of Core 1. These radiolarians indicate an approximate Campanian age for Unit II.

Core 2 of Hole 452 and Cores 1 and 2 of Hole 452A contain rare ichthyoliths that range in age from Miocene to Recent. Core 3 of Hole 452A contains abundant forms that appear to be of Miocene age. Reworked Cretaceous ichthyoliths were also encountered in Unit I.

No foraminifers were recovered from any of the cores.

\section{Nannofossils}

Four samples from Holes 452 and $452 \mathrm{~A}$ were found to contain one moderately preserved nannofossil specimen each, even though sample depth is well below the Carbonate Compensation Depth. Age-indicative species place the pelagic clay at Site 452 in the late Pleistocene Gephyrocapsa oceanica Zone, if these specimens are indigenous.

\section{Radiolarians}

Radiolarians are sparse and generally poorly preserved in the pelagic clay (Unit I) at this site. Species are seldom identifiable, and ages (based on radiolarians) are indeterminate.

Cretaceous radiolarians from cherts at the bottom of the hole and free specimens presumably derived from interbedded radiolarian muds belong to the same assemblage. Although preservation is poor (specimens infilled with, and recrystallized to, microcrystalline quartz), some species can be recognized, indicating the $\mathrm{Am}$ phiphydax enesseffi Zone of Riedel and Sanfilippo (1974), of approximately Campanian age.

\section{Ichthyoliths (Patricia S. Doyle, Scripps Institution of Oceanography)}

Fish remains occur in the sedimentary section at Site 452. They are abundant and well preserved in Core 3 of Hole $452 \mathrm{~A}$, but otherwise generally rare.

Sample 452-2,CC contains a few undescribed forms which suggest an age of middle Miocene or younger.

In Cores 1 and 2 of Hole 452A, ichthyoliths are rare. One identifiable form ranges from early Miocene to the present.

Ichthyoliths are abundant in Core 3 with the majority of forms undescribed. The upper part appears to be Miocene and the lower part Miocene with increasing proportions of Cretaceous forms downward. Core 4 is of indeterminate age. 


\section{REGIONAL STRATIGRAPHIC SYNTHESIS}

Four DSDP sites (Sites 58, 59, 61, and 452) with a Cretaceous-Neogene disconformity have been drilled east of the Mariana Trench and along the western margin of the Pacific Plate (Table 2; Figs. 6 and 7).

At Site 452, two holes (Holes 452 and 452A) were drilled. Hole $452 \mathrm{~A}$ penetrated 46.5 meters of sediments-25 meters of Neogene-Quaternary pelagic clay and 21.5 meters of Late Cretaceous radiolarian mudstone and chert. The sedimentary column is extremely thin compared with Sites 58,59 , and 61 to the south (Fig. 7). A hiatus separates Neogene from Upper Cretaceous sediments. Carbonates are completely absent from the sequence, and the Upper Cretaceous is siliceous.

The observed presence of coarse sand layers within the pelagic clay is unusual. Judging from the constituent rock grains, including chert and manganese nodules, these layers have probably been derived from Mesozoic rocks exposed near the site.

At Site 58 (Fischer, Heezen, et al., 1971), 143 meters of pelagic sediments of Pleistocene to early Miocene (possibly latest Oligocene) age were penetrated. The sediments are nannofossil oozes with an admixture of diatoms and radiolarians. Clasts, including some from shallow water, occur in well-sorted sands dispersed in an ooze matrix.

At Site 59 (Fischer, Heezen, et al., 1971), 134 meters of Cretaceous cherty and ashy clay were penetrated. Neogene brown clays overlie a probably very condensed section of Paleocene and Eocene clay containing traces of chalk. The hole bottomed in Cretaceous cherty brown clays with a bed of lithified ash. At Site 61, soft Neogene sediments, including brown lower Miocene radiolarian clays, overlie Upper Cretaceous cristobalitic mudstone associated with tuff and minor chert which rest on, and may be interbedded with, amygdaloidal basalt.

All of these sites, in common with others in the northwest Pacific east of the Mariana, Bonin, and Japan Trenches, delineate a region where Cretaceous or even Upper Jurassic cherts are overlain uncomformably by much younger pelagic clays (Fig. 6). Drilling at Sites $48,49,50,196,306$, and 307 , south and southeast of the Shatsky Rise but north of the Mid-Pacific Mountains, has revealed that the pelagic clays immediately above the unconformity are Quaternary (Fischer, Heezen, et al., 1971; Heezen, MacGregor, et al., 1973; Larson,

Table 2. Location of sites with Cretaceous disconformities.

\begin{tabular}{cccccc}
\hline Site & Leg & Latitude & Longitude & $\begin{array}{c}\text { Penetration } \\
(\mathrm{m})\end{array}$ & $\begin{array}{c}\text { Water Depth } \\
(\mathrm{m})\end{array}$ \\
\hline $58^{\mathrm{a}}$ & 6 & $9^{\circ} 14.1^{\prime} \mathrm{N}$ & $144^{\circ} 25.1^{\prime} \mathrm{E}$ & 173 & $4503(58.1)$ \\
$59^{\mathrm{a}}$ & 6 & $11^{\circ} 46.8^{\prime} \mathrm{N}$ & $14^{\circ} 349^{\prime} \mathrm{E}$ & 134 & 5554 \\
$61^{\mathrm{b}}$ & 7 & $12^{\circ} 05.02^{\prime} \mathrm{N}$ & $14^{\circ} 03.70^{\prime} \mathrm{E}$ & 330 & 5570 \\
$452^{\mathrm{c}}$ & 60 & $17^{\circ} 40.17^{\prime} \mathrm{N}$ & $148^{\circ} 37.75^{\prime} \mathrm{E}$ & 46.5 & 5870 \\
\hline
\end{tabular}

a Fischer et al., 1971.

b Winterer et al., 1971.

c This work.
Moberly et al., 1975). This is shown on the stippled region on Figure 6.

Thus, to the north and to the south of this region of the Cretaceous-Quaternary unconformity, Miocene sediments rest on the Cretaceous (Sites 303, 304, 194, 195, 61 , and 452). Reports of pre-Miocene sediments at Site 59 (Paleocene) and 436 (Eocene?) are controversial, representing either reworking or very condensed sections.

It seems a paradox that this deep ocean basin has so large a hiatus (Late Cretaceous-Neogene or Quaternary). The past horizontal and vertical motions of the Pacific plate (Lancelot and Larson, 1975) and bottom water currents (van Andel et al., 1975) could provide some constraints to establish a balance between erosion, non-deposition, and sediment-accumulating rates.

\section{Interstitial Water Geochemistry}

One sample each from Holes 452 and $452 \mathrm{~A}$ was taken for pore water chemistry less than 10 meters below the mudline. Data are reported in Gieskes (this volume). Apart from having slightly lower $p \mathrm{H}$ and magnesium, the pore waters in these samples resemble sea water. One additional sample was taken from Core 3 of Hole $452 \mathrm{~A}$ at 23.9 meters below the mudline. Salinity, chlorinity, magnesium, and calcium are all higher in this than in the other samples. This may reflect take-up of water into authigenic minerals (clays and zeolites), which are more abundant in the lower part of Core 3 than higher in the hole. The residual pore water thus is higher in all dissolved constituents.

\section{PHYSICAL PROPERTIES}

The following physical properties were measured on samples taken from Holes 452, 452A, and from the site survey piston cores SP-1A: compressional wave velocity, wet-bulk density, salt-corrected water content, porosity. Acoustic impedance and grain density were also determined. The results of these measurements are summarized in Tables 3 through 5. In addition to the above, thermal conductivity measurements were made on the split cores, no sample needing to be extracted for this technique (Horai, this volume).

\section{Sonic Velocity}

All sonic velocity measurements were made along the direction of the cores (essentially vertical). The pelagic clays of both holes, Holes 452 and $452 \mathrm{~A}$, had average velocities of $1.52 \mathrm{~km} / \mathrm{s}$ and showed no significant variation with depth. For comparison, the sound velocity in the bottom water at this site is $1.56 \mathrm{~km} / \mathrm{s}$ (interpolated from Matthews Tables, Area 42). The average velocity for the Kana Keoki core was $1.50 \mathrm{~km} / \mathrm{s}$, perhaps indicating that this core was less disturbed than the Glomar Challenger cores. Fragments of hard rock obtained from near the bottom of Hole 452A gave much higher velocities, a chert fragment measuring $4.50 \mathrm{~km} / \mathrm{s}$.

Wet-Bulk Density, Water Content, and Porosity

A proportion of the sonic velocity samples were subjected to GRAPE Special 2-minute counts for wet-bulk 


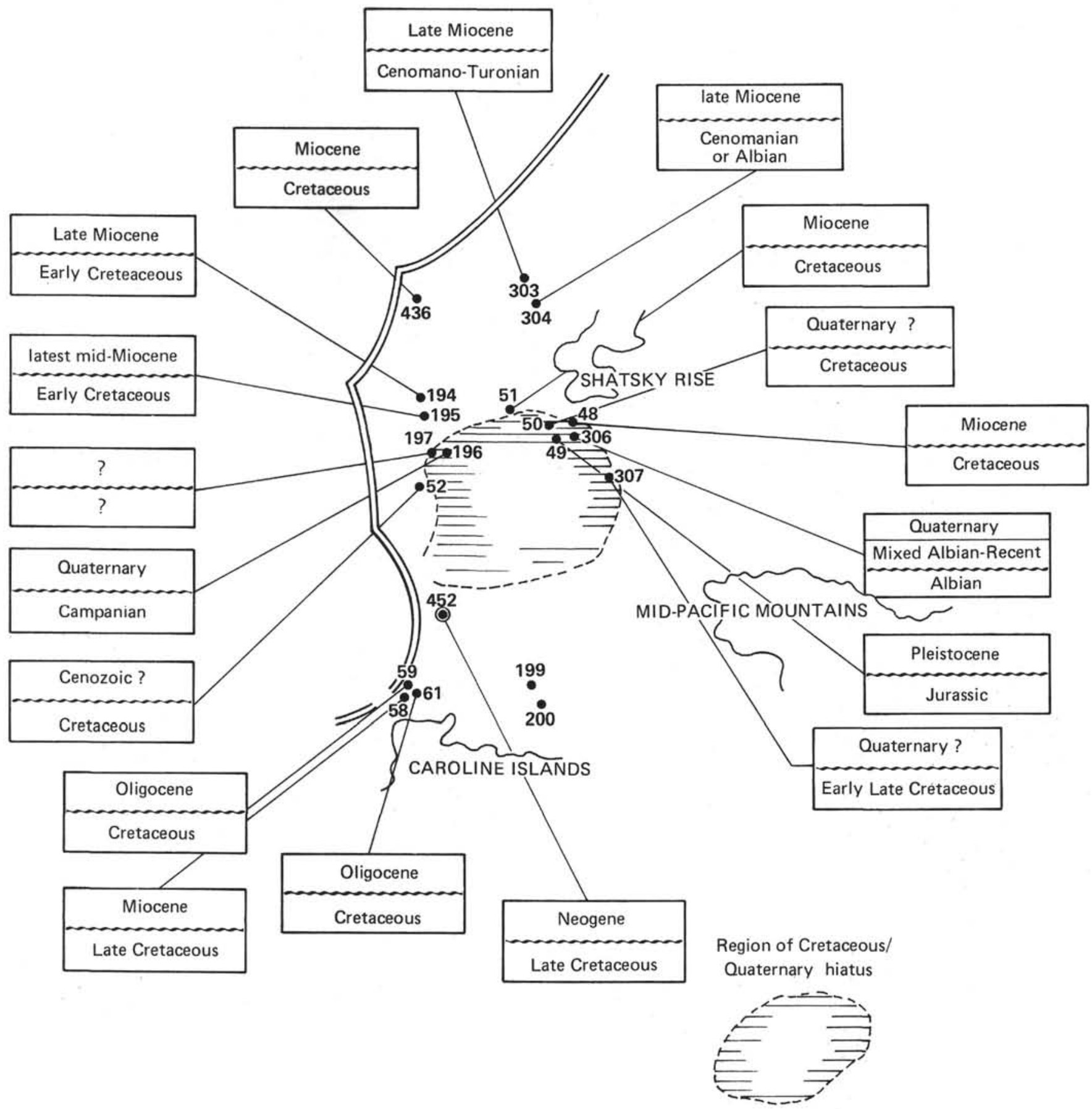

Figure 6. Stratigraphic relationship in DSDP drill sites in the northwest Pacific.

density determination. The wet-bulk density, water content, and porosity of these same samples were subsequently determined by gravimetric methods. The wetbulk density values determined by the two methods generally agree to within a few per cent. Where large discrepancies occurred, the GRAPE density was the smaller, possibly because of small cracks in the pelagic clay samples. The gravimetric density is considered the most accurate in those cases.

The average wet-bulk density of the pelagic clays was $1.33 \mathrm{~g} / \mathrm{cm}^{3}$, showing no significant variation with depth. A mudstone fragment near the bottom of Hole $452 \mathrm{~A}$ had a density of $2.02 \mathrm{~g} / \mathrm{cm}^{3}$, and a chert fragment $2.42 \mathrm{~g} / \mathrm{cm}^{3}$. Water content for the pelagic clay averaged 


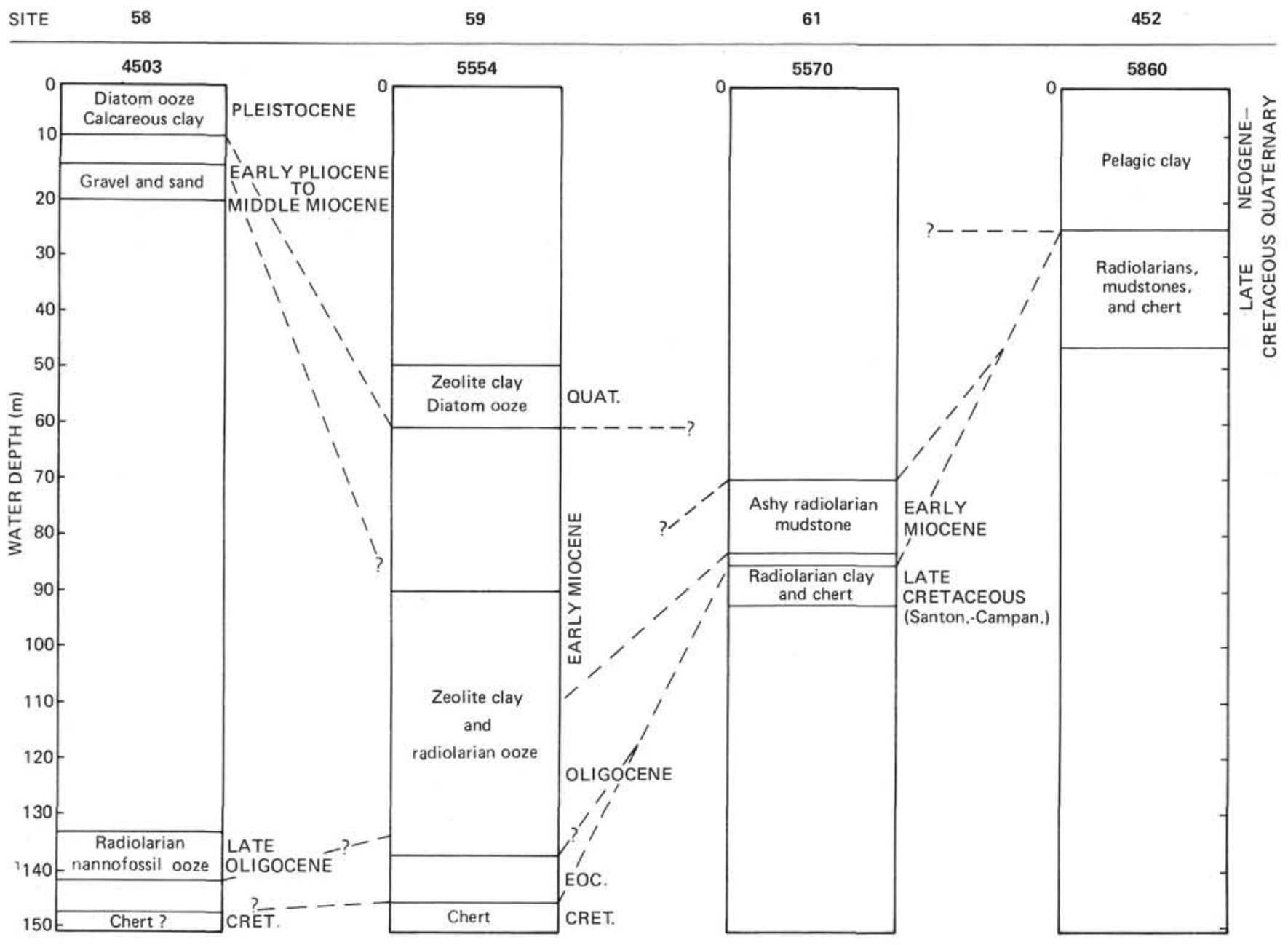

Figure 7. Stratigraphic columns for Sites 58, 59, 61, and 452 in the northwest Pacific.

Table 3. Physical properties measurements, Hole 452.

\begin{tabular}{|c|c|c|c|c|c|c|}
\hline $\begin{array}{c}\text { Sample } \\
\text { (interval in } \mathrm{cm} \text { ) }\end{array}$ & $\begin{array}{c}\text { Sound } \\
\text { Velocity } \\
\text { (vertical) } \\
(\mathrm{km} / \mathrm{s})\end{array}$ & $\begin{array}{l}\text { GRAPE } \\
\text { 2-minute } \\
\text { Wet-Bulk } \\
\text { Density } \\
\left(\mathrm{g} / \mathrm{cm}^{3}\right)\end{array}$ & $\begin{array}{c}\text { Water } \\
\text { Content } \\
\text { (salt } \\
\text { corrected) } \\
(\%)\end{array}$ & $\begin{array}{c}\text { Porosity } \\
(\%)\end{array}$ & $\begin{array}{l}\text { Wet-Bulk }{ }^{b} \\
\text { Density } \\
\left(\mathrm{g} / \mathrm{cm}^{3}\right)\end{array}$ & $\begin{array}{c}\text { Acoustic } \\
\text { Impedance } \\
\left(\mathrm{g} / \mathrm{cm}^{2} \mathrm{~s} \times 10^{5}\right)\end{array}$ \\
\hline $1-1,30-32$ & 1.506 & & & & & \\
\hline $1-2,40-42$ & 1.491 & & 60.24 & 79.68 & 1.36 & 2.03 \\
\hline $1-3,60-62$ & 1.522 & & & & & \\
\hline $1-4,44-46$ & 1.528 & & & & & \\
\hline $1-5,64-66$ & 1.527 & & & & & \\
\hline $1-6,80-82$ & 1.572 & & 56.52 & 78.07 & 1.41 & 2.22 \\
\hline $2-1,60-62$ & 1.505 & & & & & \\
\hline $2-2,64-66$ & 1.517 & & & & & \\
\hline $2-3,76-78$ & 1.521 & & 62.26 & 80.20 & 1.32 & 2.01 \\
\hline $2-4,58-60$ & 1.520 & & & & & \\
\hline $2-5,55-57$ & 1.507 & & 64.54 & 81.51 & 1.29 & 1.94 \\
\hline $2-6,80-82$ & 1.516 & & & & & \\
\hline $3-1,90-92$ & 1.507 & 1.22 & 66.73 & 82.92 & 1.27 & 1.91 \\
\hline $3-2,80-82$ & 1.512 & 1.34 & 61.97 & 80.37 & 1.33 & 2.01 \\
\hline $3-3,80-82$ & 1.507 & 1.38 & & & & 2.08 \\
\hline $3-4,104-106$ & 1.519 & 1.30 & 64.64 & 81.75 & 1.30 & 1.97 \\
\hline $3-5,54-56$ & 1.511 & 1.21 & 63.80 & 81.44 & 1.31 & 1.98 \\
\hline $304,145-147$ & 1.536 & 1.41 & & & & 2.17 \\
\hline Average & 1.518 & 1.31 & 62.59 & 80.74 & 1.32 & 2.03 \\
\hline
\end{tabular}

${ }_{\mathrm{b}}^{\mathrm{a}}$ Porosity $=$ salt-corrected water content $\times$ wet-bulk density (gravimetric) $/ 1.025$.

b Gravimetric method. 
Table 4. Physical properties measurements, Hole 452A.

\begin{tabular}{|c|c|c|c|c|c|c|c|}
\hline $\begin{array}{l}\text { Sample } \\
\text { (interval in } \mathrm{cm} \text { ) }\end{array}$ & $\begin{array}{c}\text { Sound } \\
\text { Velocity } \\
\text { (vertical) } \\
\mathrm{km} / \mathrm{s}\end{array}$ & $\begin{array}{c}\text { GRAPE } \\
\text { 2-minute } \\
\text { Wet-Bulk } \\
\text { Density } \\
\left(\mathrm{g} / \mathrm{cm}^{3}\right)\end{array}$ & $\begin{array}{c}\text { Water } \\
\text { Content } \\
\text { (salt } \\
\text { corrected) } \\
(\%)\end{array}$ & $\begin{array}{l}\text { Porosity } \\
(\%)\end{array}$ & $\begin{array}{l}\text { Wet-Bulkb } \\
\text { Density } \\
\left(\mathrm{g} / \mathrm{cm}^{3}\right)\end{array}$ & $\begin{array}{c}\text { Acoustic } \\
\text { Impedance } \\
\left(\mathrm{g} / \mathrm{cm}^{2} \mathrm{~s} \times 10^{5}\right)\end{array}$ & $\begin{array}{l}\text { Rock } \\
\text { Type }\end{array}$ \\
\hline $1-2,55-57$ & 1.512 & 1.35 & 65.22 & 83.70 & 1.31 & 1.98 & Pelagic clay \\
\hline $1-3,115-117$ & 1.530 & & & & & & Pelagic clay \\
\hline $1-4,81-83$ & 1.553 & 1.43 & 56.09 & 78.15 & 1.43 & 2.22 & Pelagic clay \\
\hline $1-5,36-38$ & 1.512 & 1.37 & 61.89 & 81.28 & 1.35 & 2.04 & Pelagic clay \\
\hline $1-6,40-42$ & 1.492 & & & & & & Pelagic clay \\
\hline $2-1,60-62$ & 1.506 & 1.31 & 66.22 & 83.13 & 1.29 & 1.94 & Pelagic clay \\
\hline $2-2,54-56$ & 1.506 & 1.32 & 66.34 & 82.66 & 1.28 & 1.93 & Pelagic clay \\
\hline $3-1,125-127$ & 1.514 & & & & & & Pelagic clay \\
\hline $3-2,104-106$ & 1.521 & 1.12 & 64.04 & 82.19 & 1.31 & 1.99 & Pelagic clay \\
\hline $3-3,55-57$ & 1.520 & & & & & & Pelagic clay \\
\hline $3-4,102-104$ & 1.517 & & & & & & Pelagic clay \\
\hline $3-5,65-67$ & 1.520 & $\underline{1.39}$ & $\underline{54.18}$ & 74.32 & 1.41 & 2.14 & Pelagic clay \\
\hline Average & 1.517 & 1.33 & 62.00 & 80.78 & 1.34 & 2.03 & \\
\hline $4, \mathrm{CC}$ & 2.99 & 2.02 & 11.12 & 21.97 & 2.02 & 6.04 & $\begin{array}{l}\text { Radiolarian-rich } \\
\text { mudstone fragment }\end{array}$ \\
\hline 5022 & 4.50 & 2.42 & & & & 10.89 & Chert fragment \\
\hline
\end{tabular}

Porosity $=$ salt-corrected water content $\times$ wet-bulk density (gravimetric) $/ 1.025$

${ }^{b}$ Gravimetric method.

Table 5. Physical properties measurements, SP-1A.

\begin{tabular}{|c|c|c|c|c|c|c|}
\hline $\begin{array}{c}\text { Sample } \\
\text { (interval in } \mathrm{cm} \text { ) }\end{array}$ & $\begin{array}{c}\text { Sound } \\
\text { Velocity } \\
\text { (vertical) } \\
(\mathrm{km} / \mathrm{s})\end{array}$ & $\begin{array}{l}\text { GRAPE } \\
\text { 2-minute } \\
\text { Wet-Bulk } \\
\text { Density } \\
\left(\mathrm{g} / \mathrm{cm}^{3}\right)\end{array}$ & $\begin{array}{c}\text { Water } \\
\text { Content } \\
\text { (salt } \\
\text { corrected) } \\
\text { (\%) }\end{array}$ & $\begin{array}{c}\text { Porosity }{ }^{a} \\
(\%))\end{array}$ & $\begin{array}{l}\text { Wet-Bulkb } \\
\text { Density } \\
\left(\mathrm{g} / \mathrm{cm}^{3}\right)\end{array}$ & $\begin{array}{c}\text { Acoustic } \\
\text { Impedance } \\
\left(\mathrm{g} / \mathrm{cm}^{2} \mathrm{~s} \times 10^{5}\right)\end{array}$ \\
\hline SP-1A-0, 40-42 & 1.502 & & & & & \\
\hline SP-IA-I, 74-76 & 1.507 & & & & & \\
\hline SP-1A-2, 74-76 & 1.504 & & & & & \\
\hline SP-1A-3, 78-80 & 1.507 & & 67.14 & 83.84 & 1.28 & 1.93 \\
\hline SP-1A-4, 80-82 & 1.508 & & & & & \\
\hline SP-1A-5, 75-77 & 1.466 & & 59.95 & 80.29 & 1.37 & 2.01 \\
\hline SP-1A-6, 64-66 & 1.508 & & & & & \\
\hline Average & $=1.500$ & & 63.55 & 82.07 & 1.33 & 1.97 \\
\hline
\end{tabular}

a Porosity $=$ salt-corrected water content $\times$ wet-bulk density (gravimetric) $/ 1.025$.

Gravimetric method.

62 per cent and porosity 81 per cent. The mean grain density of the pelagic clay was $2.63 \mathrm{~g} / \mathrm{cm}^{3}$.

\section{Acoustic Impedance}

The acoustic impedance of the pelagic clay averaged $2.03 \times 10^{5} \mathrm{~g} / \mathrm{cm}^{2}$ for both Holes 452 and 452A. At the bottom of Hole 452A, the radiolarian mudstone fragment had an impedance of $6.04 \times 10^{5} \mathrm{~g} / \mathrm{cm}^{2}$ and the chert fragment $10.89 \times 10^{5} \mathrm{~g} / \mathrm{cm}^{2}$. It is likely that this large increase in impedance corresponds to the first subbottom reflector on the $3.5-\mathrm{kHz}$ PDR record at 0.04 (Fig. 3). The mean velocity of $1.52 \mathrm{~km} / \mathrm{s}$ for the pelagic clays would then place this boundary at 30.4 meters below the bottom.

\section{PALEOMAGNETICS}

No paleomagnetic measurements were made at this site.

\section{SUMMARY AND CONCLUSIONS}

The principal objectives of Site 452-to provide an oceanic plate reference section for the South Philippine-Mariana Arc transect of DSDP sites, and to date the northern Mariana Basin-were not met when we had to abandon the hole in the face of unexpectedly shallow chert layers. Seismic data indicate a minimum of 200 meters of sediment below the chert, but neither this sediment nor the top of the igneous oceanic crust was sampled or dated.
In Hole $452 \mathrm{~A}$, the drill penetrated over 25 meters of Neogene-Quaternary pelagic clays before going directly into Cretaceous siliceous mudstone (porcellanite) and chert. The lack of any significant thickness of Neogene sediments above the cherts is a phenomenon that has been encountered at previous drill sites on northwestern Pacific plate Mesozoic crust. A widespread Late Cretaceous to Quaternary hiatus extends from just west of the Mid-Pacific Mountains to the Japan/Bonin/Mariana Trenches, and from south of the Shatsky Rise to somewhere north of Site 452 in the northern Mariana Basin. In addition to Site 452, other Mesozoic crust in the western Pacific has a similar, but shorter Cretaceous to Miocene (or later Oligocene) hiatus. The widespread occurrence of so large a hiatus may be of great significance in the studies of past plate motions and paleophysical oceanography.

\section{REFERENCES}

Fischer, A. G., Heezen, B. C., et al., 1971. Init. Repts. DSDP, 6: Washington (U.S. Govt. Printing Office).

Heezen, B. C., MacGregor, I. D., et al., 1973. Init. Repts. DSDP, 20: Washington (U.S. Govt. Printing Office).

Lancelot, Y., and Larson, R. L., 1975. Sedimentary and tectonic evolution of the Northwestern Pacific, Deep Sea Drilling Project, Leg 32. In Larson, R. L., Moberly, R., et al., Init. Repts. DSDP, 32: Washington (U.S. Govt. Printing Office), 925-940.

Larson, R. L., Moberly, R., et al., 1975. Init. Repts. DSDP, 32: Washington (U.S. Govt. Printing Office).

LaTraille, S., and Hussong, D. M., 1980. Crustal structure across the Mariana Island arc. In Hayes, D. E. (Ed.), Tectonic and Geologic Evolution of South East Asia: Washington (American Geophysical Union), 209-222.

Riedel, W. R., and Sanfilippo, A., 1974. Radiolaria from the southern Indian Ocean, DSDP Leg 26. In Davies, T. A., Luyendyk, B. P., et al., Init. Repts. DSDP, 26: Washington (U.S. Govt. Printing Office), 771-813.

Scientific Party, 1980. Init. Repts. DSDP, 56, 57: Washington (U.S. Govt. Printing Office).

van Andel, Tj. H., Ross, G. R., and Moore, T. C., Jr., 1975. Pacific Cenozoic hiatuses and erosion. Cenozoic history and paleooceanography of the central equatorial Pacific Ocean. Geol. Soc. Am. Mem. 143.

Winterer, E. L., Riedel, W. R., et al., 1971. Init. Repts. DSDP, 7: Washington (U.S. Govt. Printing Office). 

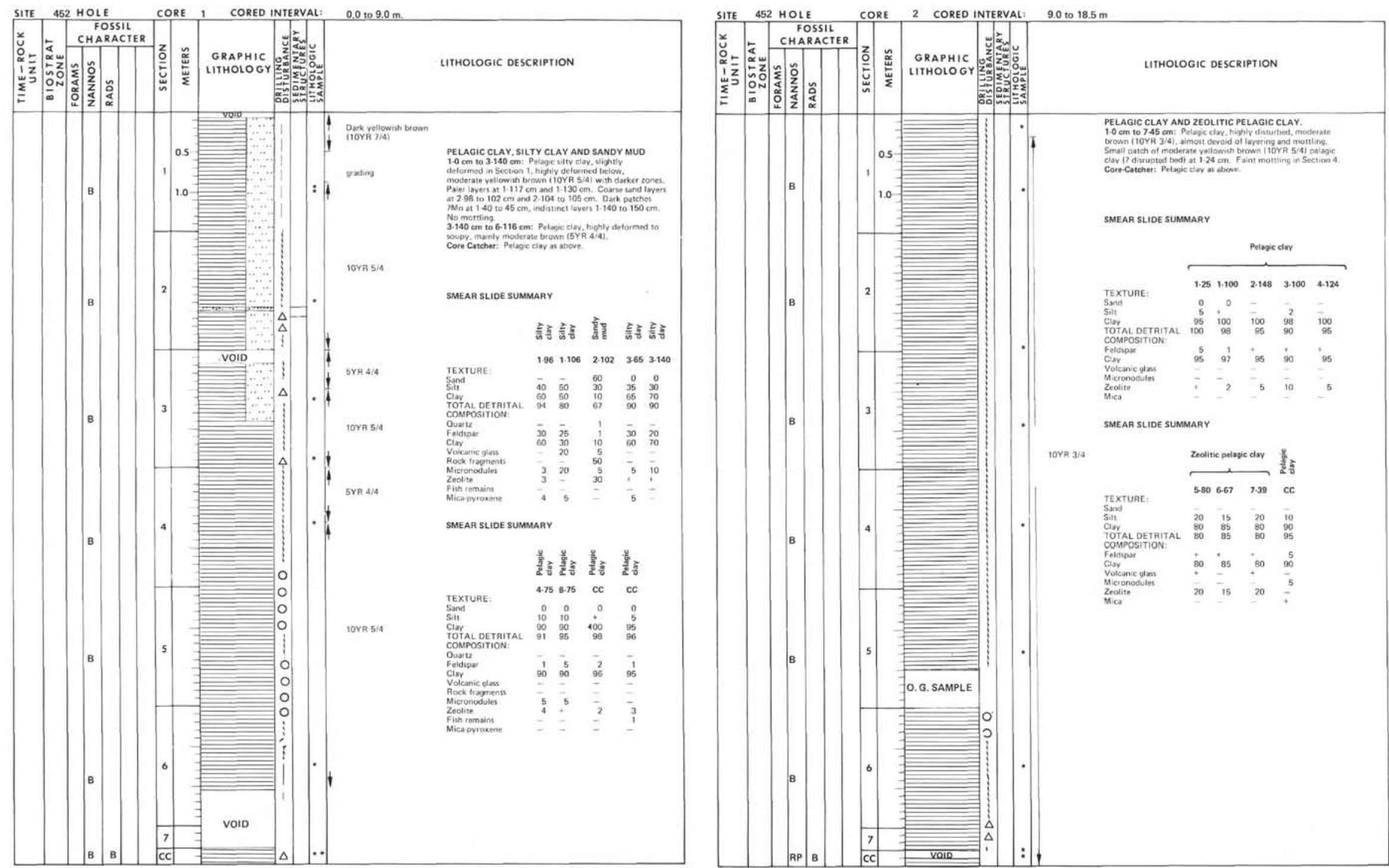


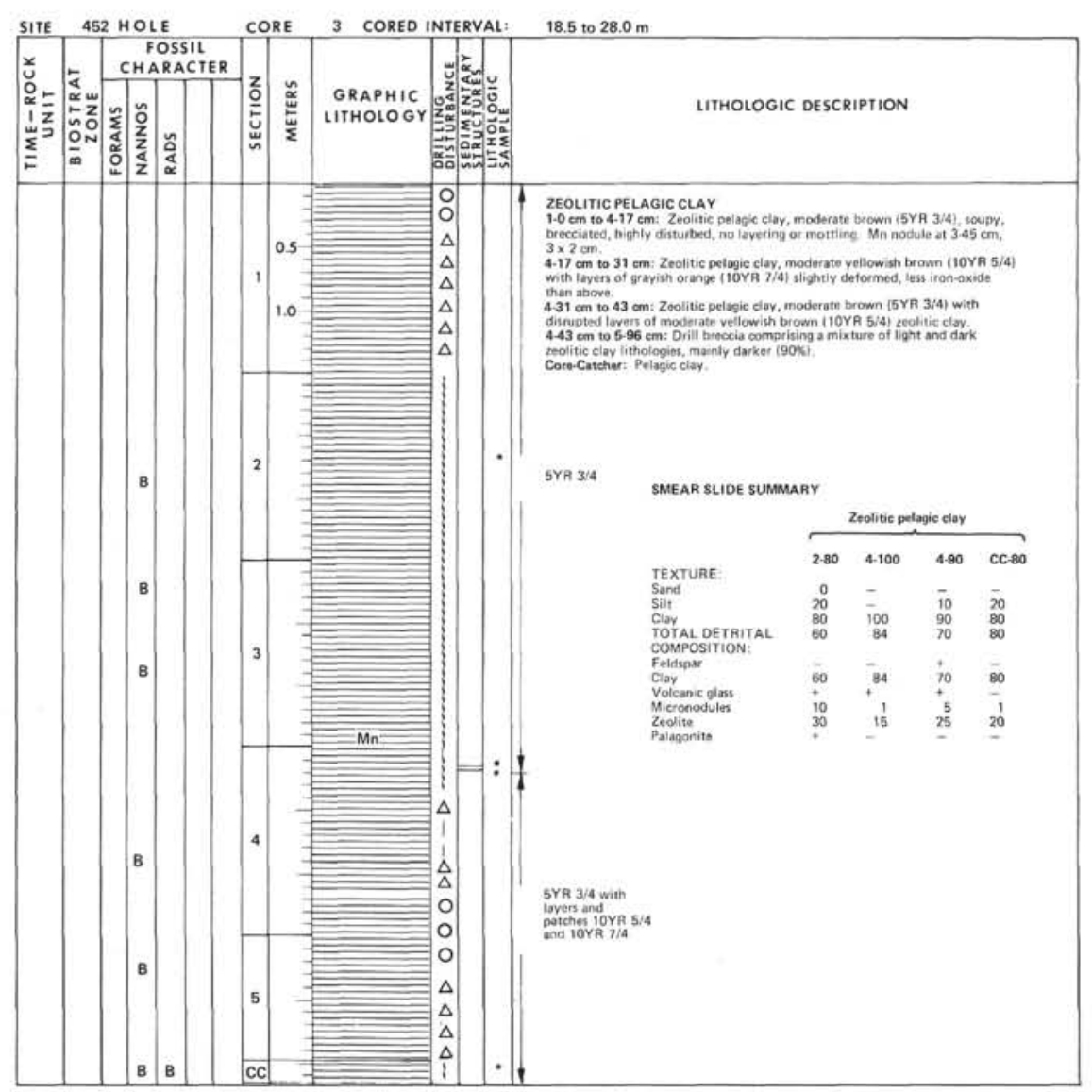



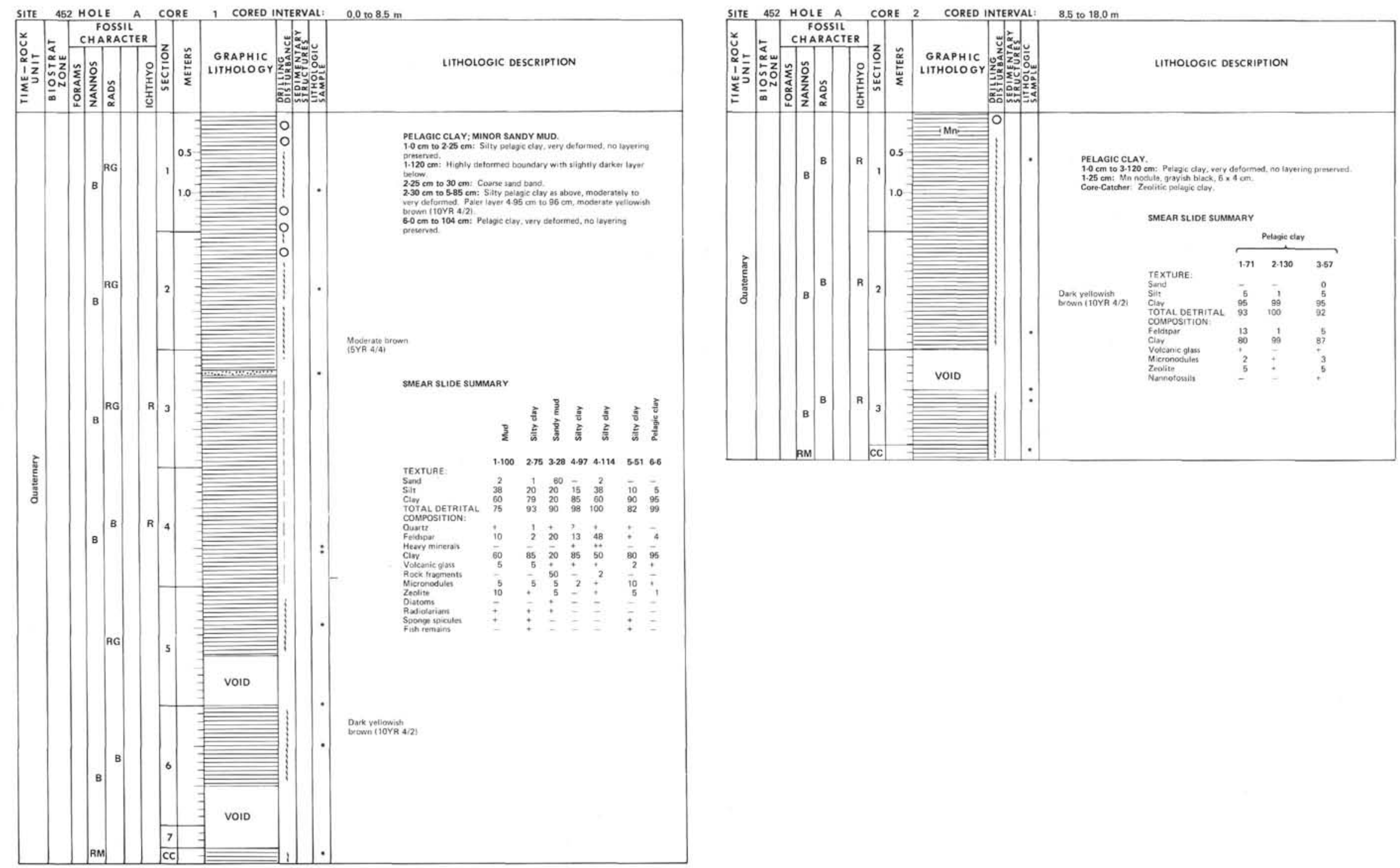

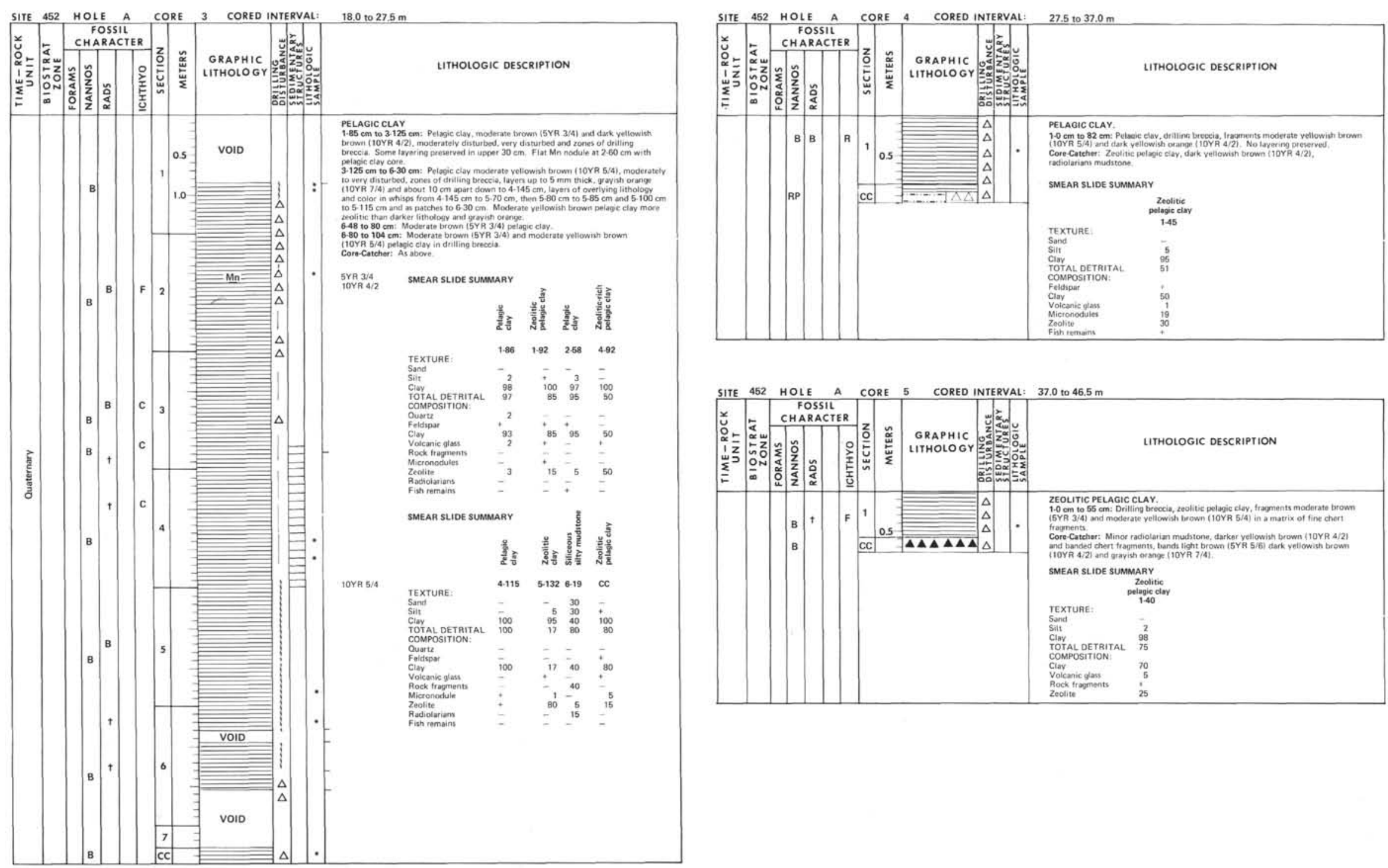

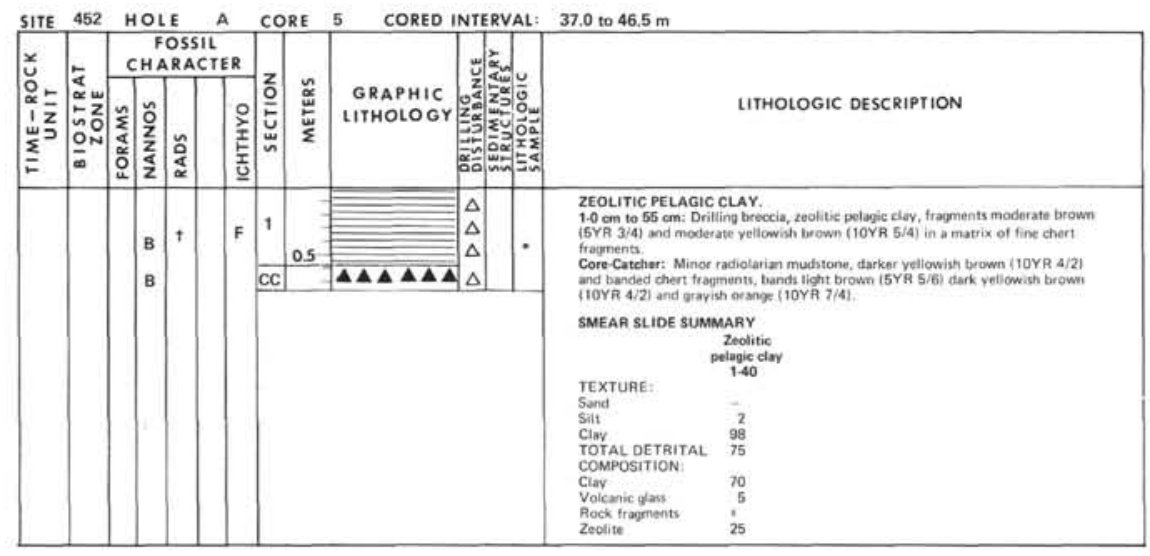




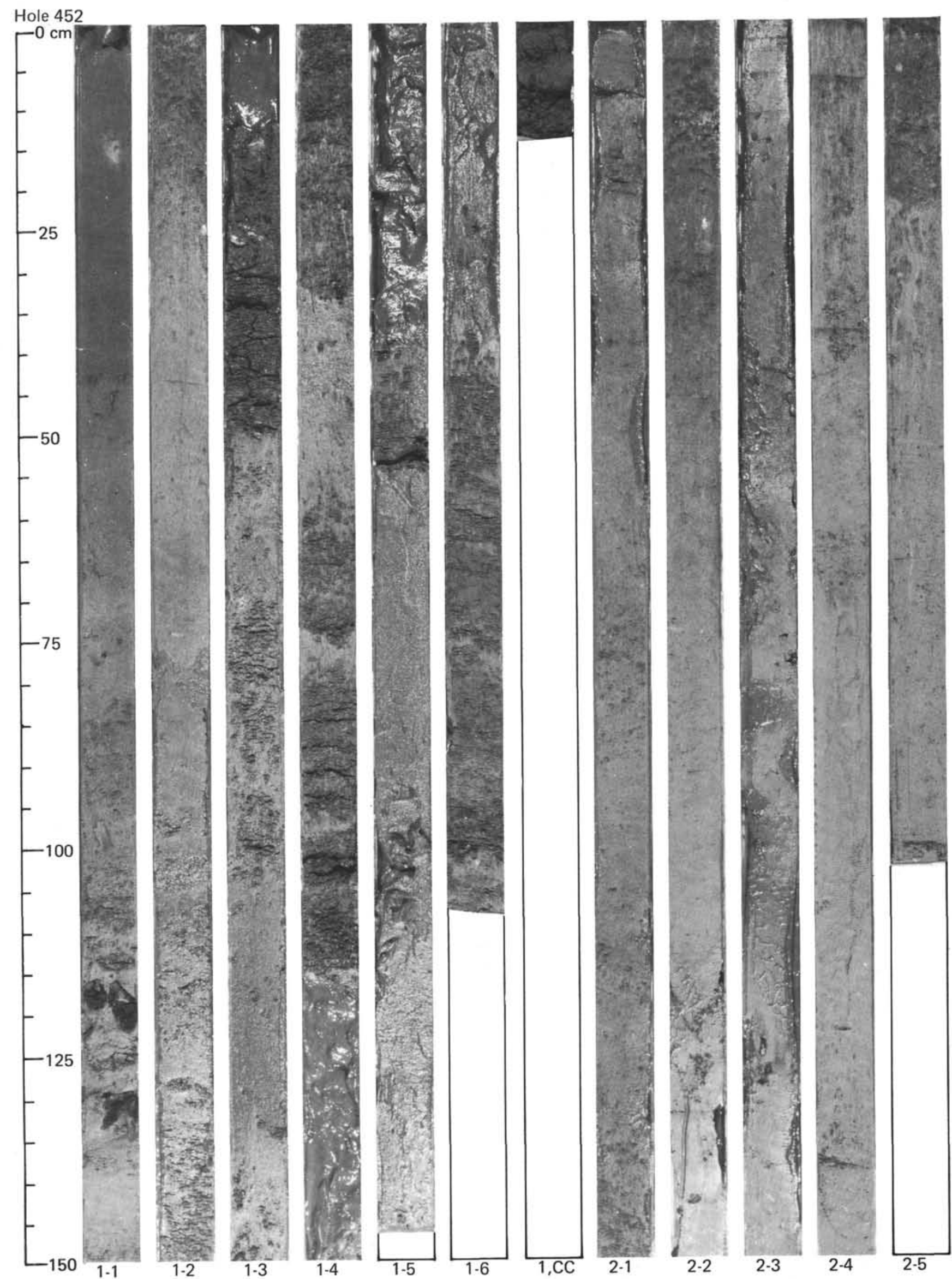


Hole 452

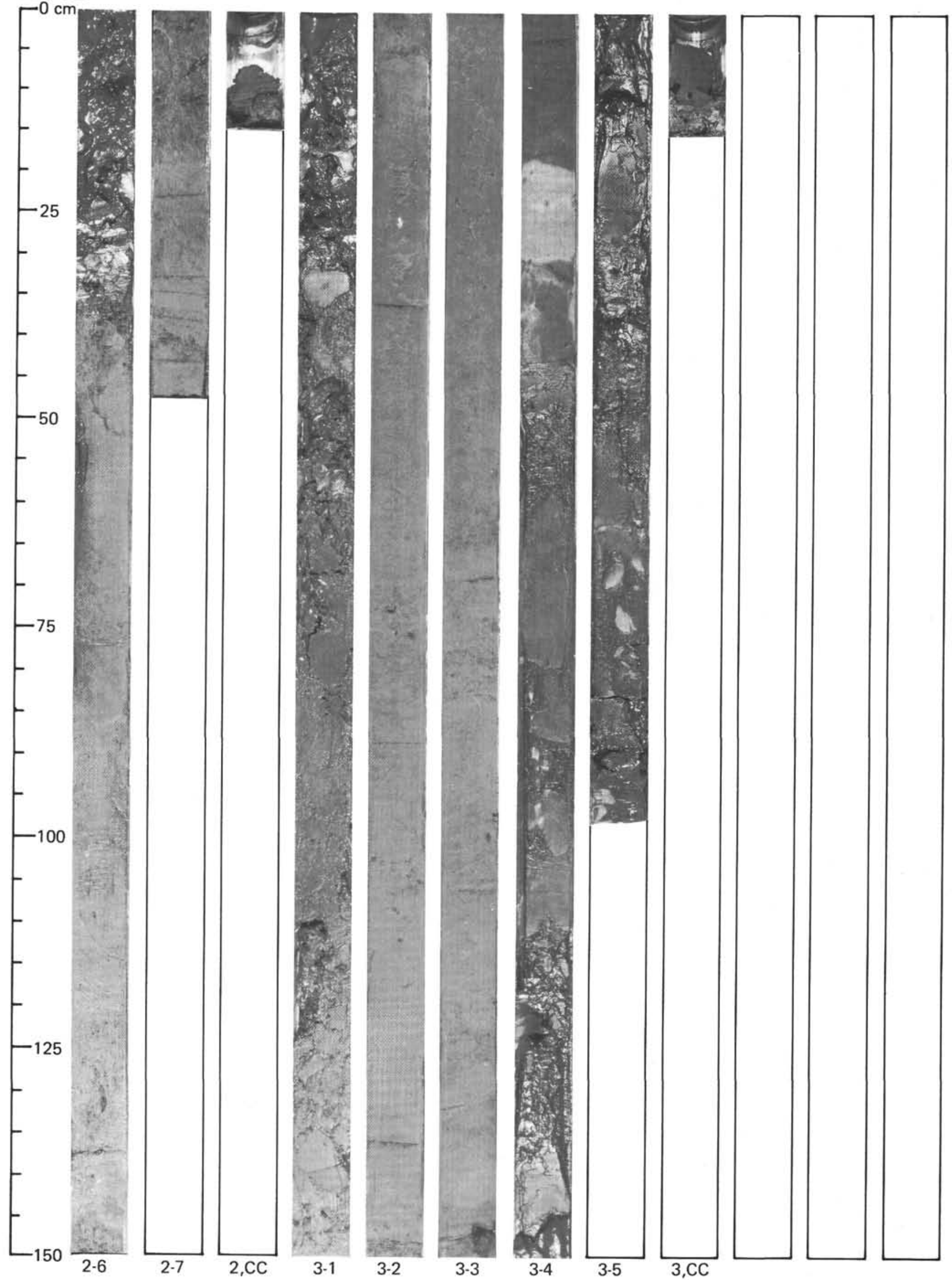


Hole 452A

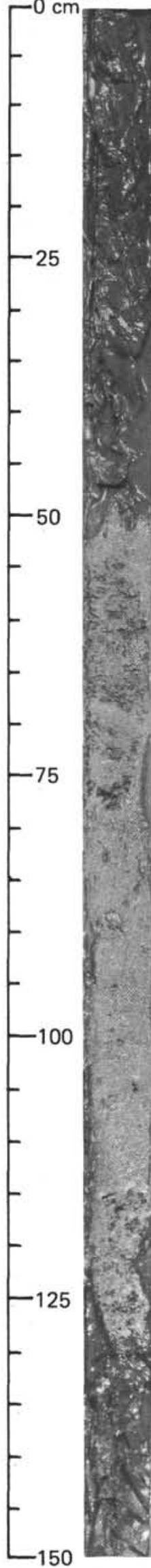

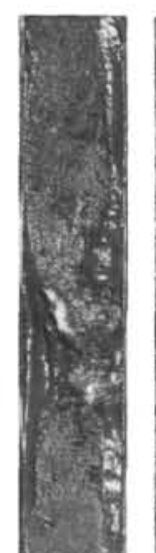
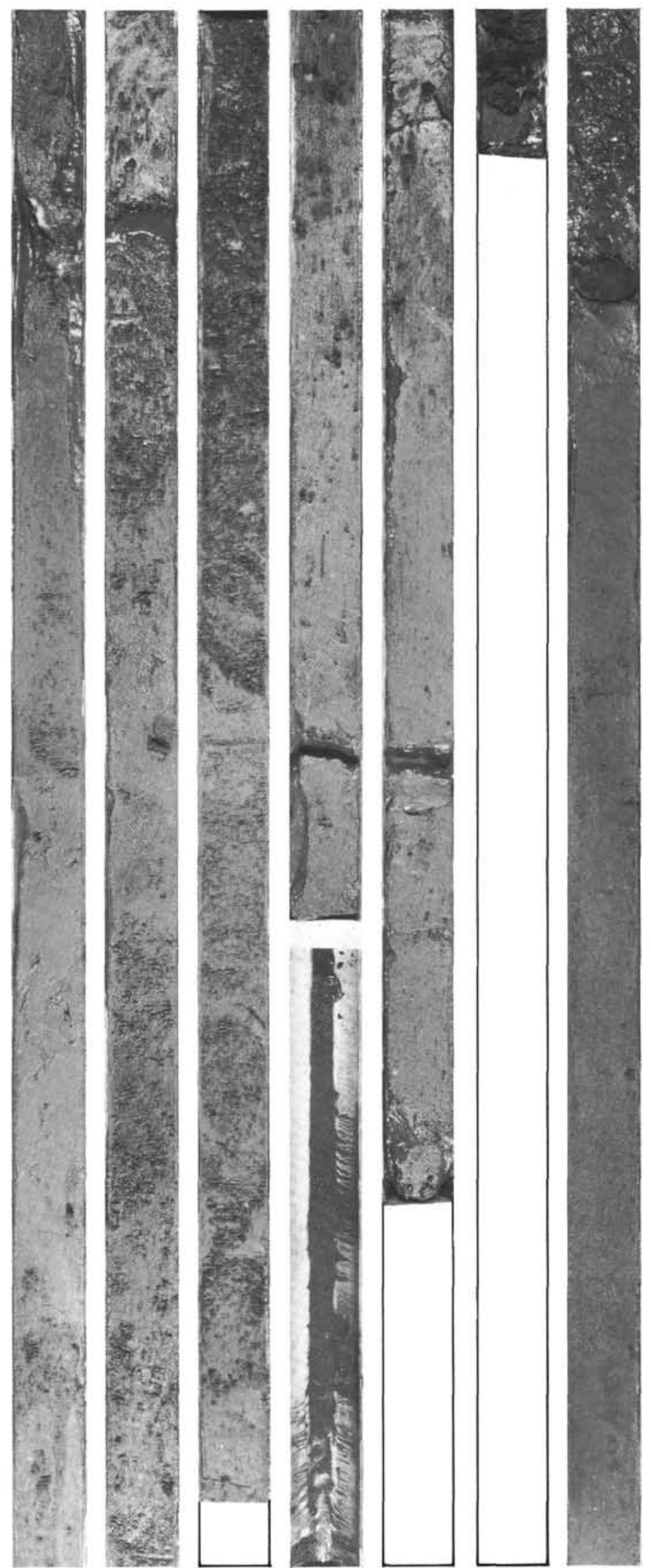

$\lim _{x \rightarrow-5}$

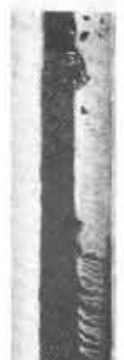

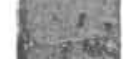
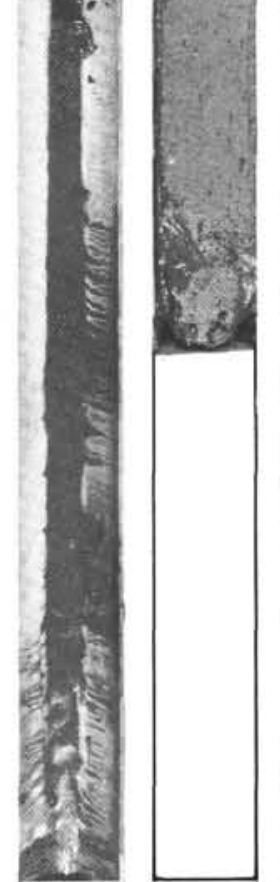
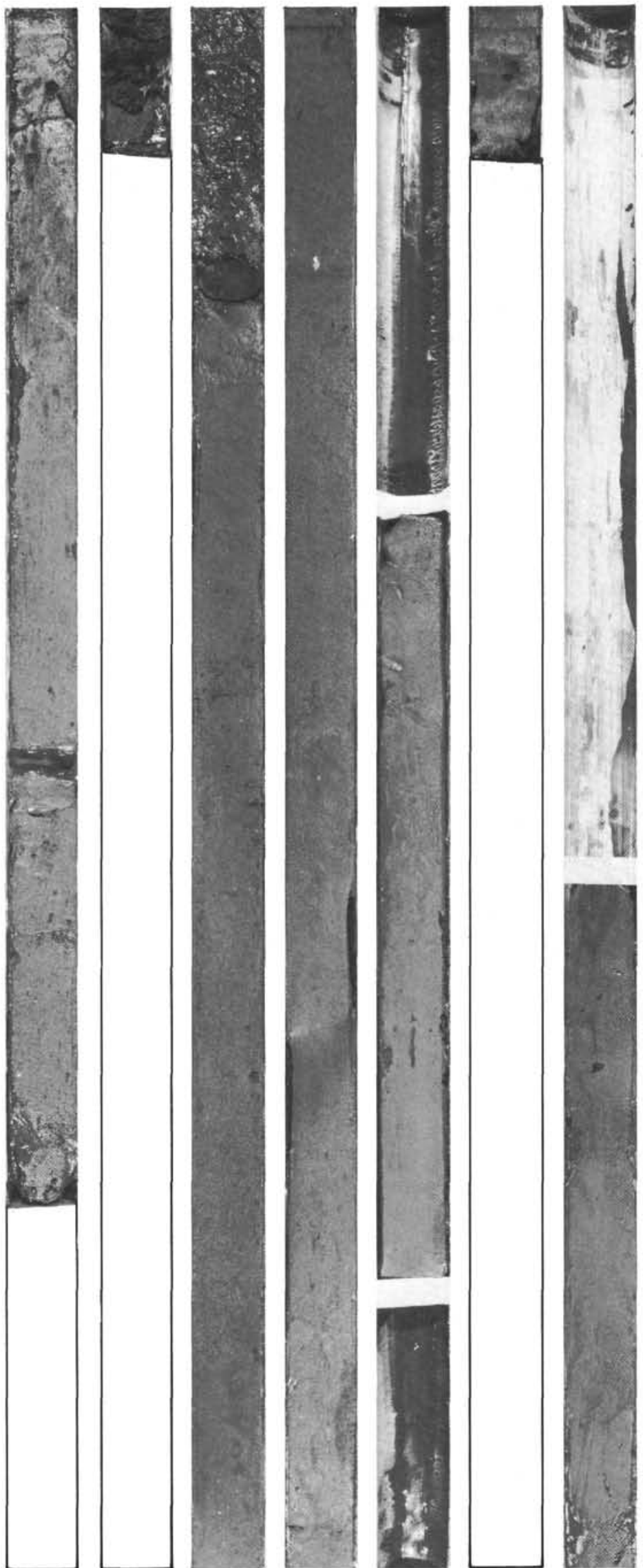
Hole 452A

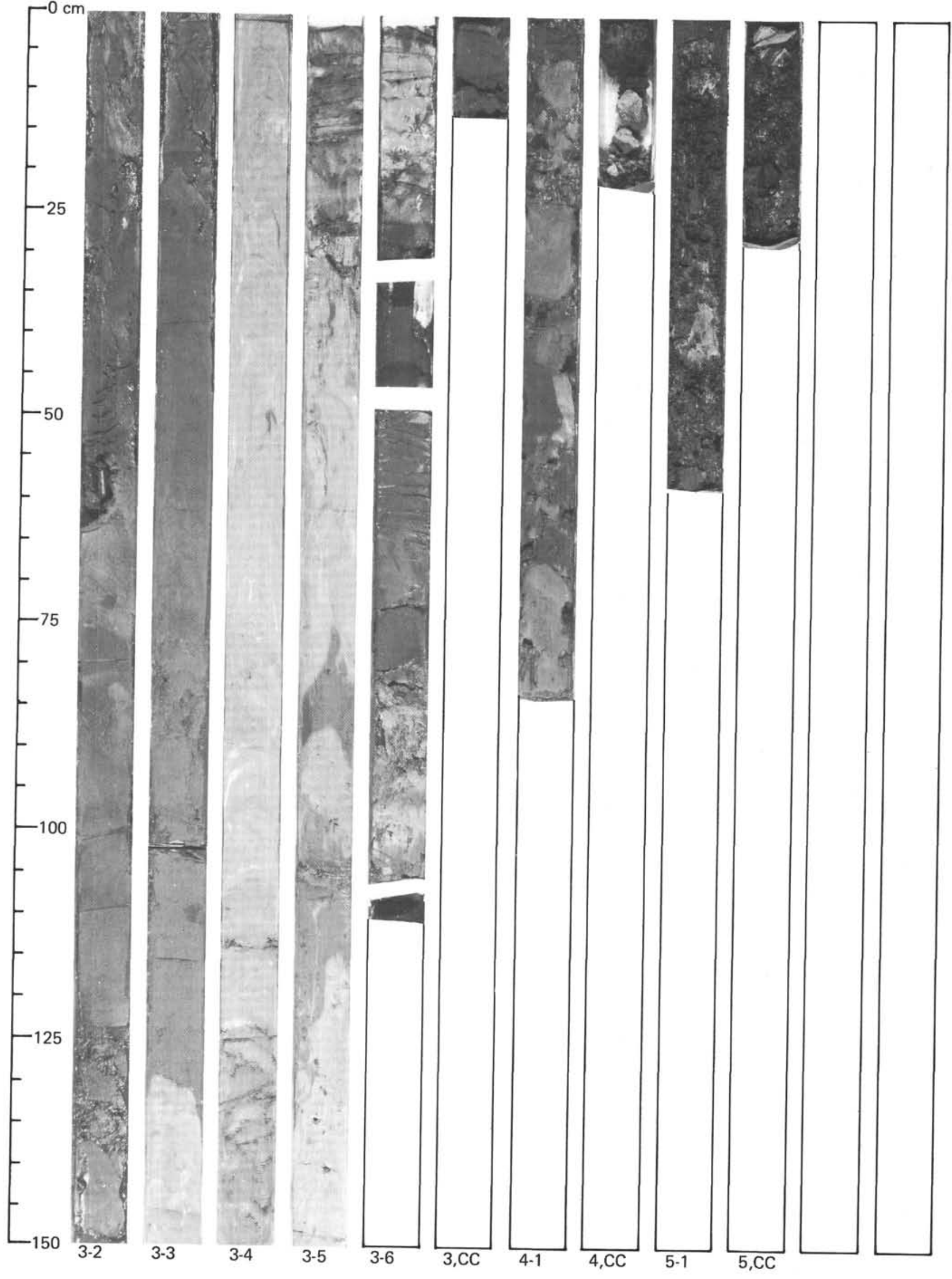

